\title{
THE NORMATIVE DIMENSION OF THE CONCEPTION OF THE INDIVIDUAL PRESENTED IN OPINIONS OF JUDGE Antonio Augusto CANÇAdo TRINDAde OF THE ICJ - FUNDAMENTAL ELEMENTS
}

\author{
ARTUR KOZLOWSKI*
}

\section{INTRODUCTION}

Antonio Augusto Cançado Trindade, retired professor of international law at the University of Brasilia, in 1995-2008 judge and Chief Justice of the International Court of Human Rights, was appointed in 2008 to the International Court of Justice for a 9-year term. Since then, he has authored a large number of separate and dissenting opinions concerning verdicts handed down by the Hague-based tribunal ${ }^{1}$. They present a relatively coherent, yet at times controversial picture of international law, with a very strong accent on the role of the individual as the point of reference in the overarching structure of the international law system ${ }^{2}$. This is a conception which Cançado

DOI: $10.1515 /$ wrlae-2015-0032

* Professor of Law at Wroclaw University, Department of International and European Law; artur.kozlowski@uwr.edu.pl

1 Advisory Opinion of the International Court of Justice (ICJ) on Accordance with International Law of the Unilateral Declaration of Independence in Respect of Kosovo, 2008 (Separate opinion); Pulp Mills case (Argentina v Uruguay), 2010 (Separate opinion); Advisory Opinion on Judgment No. 2867 of the Administrative Tribunal of the International Labour Organization upon a Complaint Filed against the International Fund for Agricultural Development, 2010 (Separate opinion); Application of the International Convention on the Elimination of All Forms of Racial Discrimination (Georgia v Russian Federation), 2011 (Dissenting opinion); Ahmadou Sadio Diallo case (I, II, III) (Republic of Guinea $v$ Democratic Republic of the Congo), 2012 (Separate opinions); Questions relating to the Obligation to Prosecute or Extradite (Belgium v Senegal), 2012 (Separate opinion); Jurisdictional Immunities of the State (Germany v Italy: Greece intervening), 2012 (Dissenting opinion); Request for Interpretation of the Judgment of 15 June 1962 in the Case concerning the Temple of Preah Vihear (Cambodia $v$ Thailand) (Cambodia $v$ Thailand), 2013 (Seperate opinion); Frontier Dispute (Burkina Faso v Niger), 2013 (Seperate opinion); Whaling in the Antarctic (Australia v Japan: New Zealand intervening), 2014 (Separate opinion); Obligation to Negotiate Access to the Pacific Ocean (Bolivia v Chile), 2015 (Separate opinion). Cf. Judge Antônio A. Cançado Trindade. The Construction of a Humanized International Law: A Collection of Individual Opinions (1991-2013) (Preface by Dean Spielmann, General Introduction by Andrew Drzemczewski, Brill Nijhoff, Hotei Publishing 2014).

${ }^{2}$ See Antônio Augusto Cançado Trindade, International Law for Humankind. Towards a New 
Trindade has been developing for many years ${ }^{3}$, and the presented approach is a characteristic feature of his views. However, it should be emphasized that the manner in which he captures the issue is not entirely unknown to earlier phases in the development of international law jurisprudence ${ }^{4}$. Worthy of particular attention is the consistent manner in which he has constructed a comprehensive approach to the issue under consideration, as well as his efforts at describing the normative reality as a consequence of a humanistic vision of the international legal order; in this vision, the law, including international public law, is a product of some of humanity's lasting aspirations, consistently leaving its mark on the image of public international law. Cançado Trindade emphasizes that this approach to the essence of international law contributes to limiting abuses that affect individuals, as well as grievous violations of human rights and international humanitarian law ${ }^{5}$. This basic theme is repeated throughout a range of variations and explications contained in a series of judicial writings. Absent the acceptance of this fundamental assumption, it would be impossible to maintain the entire conception within an orderly framework. The terminology used to express the

Jus Gentium ( ${ }^{\text {nd }}$ revised edn, Martinus Nijhoff Publishers 2013).

${ }^{3}$ See for example: Antônio Augusto Cançado Trindade, 'The Voluntarist Conception of International Law: A Re-Assessment' (1981) 59 Revue de droit international de sciences diplomatiques et politiques; id, 'Reflections on International Law-Making: Customary International Law and Reconstruction of Jus Gentium' in International Law and Development (Proceedings of the 1986 Conference of the Canadian Council on International Law), Ottawa, Canadian Council on International Law, 1986; id, 'Le nouveau Règlement de la Cour Interaméricaine des Droits de l'Homme: quelques réflexions sur la condition de l'individu comme sujet du Droit international' in Libertés, justice, tolérance - Mélanges en hommage au Doyen G. Cohen-Jonathan, vol. I (Bruylant 2004); id, 'Complementarity between State Responsibility and Individual Responsibility for Grave Violations of Human Rights: the Crime of State Revisited' in Maurizio Ragazzi (ed.), International Responsibility Today Essays in Memory of Oscar Schachter (Martinus Nijhoff 2005); id, A Humanizaçao do Direito Internacional, Belo Horizonte, Edit. Del Rey, 2006;

${ }^{4} \mathrm{Cf}$. the normativist approach of Hans Kelsen: The subjects of international law are - like the subjects of national law - individual human beings. [...] The statement that states as juristic persons are subjects of international law does not mean that individuals are not the subjects of the obligations, responsibilities, and rights established by that law. It only means that individual human beings are indirectly and collectively, in their capacity as organs or members of the state, subjects of the obligations, responsibilities, and rights of the state. Besides, human beings are also directly and individually subjects of obligations, responsibilities, and rights established by intenational law (Principles of International Law (The Lawbook Exchange, Ltd 2003) 114-115). Also Alf Ross, A Textbook of International Law. General Part (The Lawbook Exchange, Ltd 2006) 28: It follows from the above statement that an individual can never be capable of an international duty and consequently he cannot, either, be capable of international action. On the other hand, there is no conceptual objection to the individual being the subject of international rights, both as an interested party and as a party instituting proceedings. To what extent this is actually the case of course depends on the contents of International Law.

${ }^{5}$ Separate opinion in the case of Unilateral Declaration of Independence (Advisory Opinion) [2010] ICJ Rep 553, para. 75: Since the times of those writings, the world of course has entirely changed, but human aspirations have remained the same. The advent, over the twentieth century, of international organizations (as we came to know them nowadays), has much contributed, in a highly positive way, to put an end to abuses against human beings, and gross violations of human rights and international humanitarian law. The United Nations, in our times, has sought the prevalence of the dictates of the universal juridical conscience, particularly when aiming to secure dignified conditions of living to all peoples, in particular those subjected to oppression. 
assumption adopted by Cançado Trindade is changeable, but its core remains constant. Terms employed such as "universal juridical conscience", "ius necessarium", and "recta ratio" have come to serve as the foundation on which the entire conception is built.

\section{The role of the lawyer in the contemporary world}

An interesting aspect from the perspective of the basic conditions underlying the conception discussed here is the criteria related to the role of the lawyer in the contemporary world. Cançado Trindade stresses that the sense of the presented framework will become obvious to the lawyer who, in rejecting modernist and post-modernist traps, achieves the capacity to focus on the needs of the soul ${ }^{6}$. This leads to a particular sort of imperative and the necessity of reflection as sources of understanding the particular role and needs of the individual, including in the normative sense. If this condition is met, there should not be any greater difficulties with accepting the notion that the individual must be the essential point of reference for the international legal order. Even if some would, in the systemic sense, have trouble acknowledging the particular and absolute primacy of the individual over the primary subjectivity of the state, it is difficult not to appreciate the appeal for greater focus and deeper reflection as a condition of action and of the meaning of all conclusions, including legal ones. For Judge Cançado Trindade, the engagement of legal thinking, rejecting to an extent worn pragmatisms, is thus a conditio sine qua non of the construct. It would seem to be a suggestion that the more focused, that is, the more engaged the approach presented by a lawyer, the greater are the chances of that lawyer acknowledging that a logical consequence of general legal consciousness is the understanding that the individual must serve as the overarching category for systematizing the manner in which the international legal order is considered. It should therefore come as no surprise that both the starting point and the final ascertainment is that the lawyer-internationalist's fundamental task is to cement the right of access to justice for all people, in every situation and without regard to the barriers which must be overcome ${ }^{7}$.

\section{Ius necessarium and recta ratio}

This assumption, once adopted, leads to further primary elements

\footnotetext{
${ }^{6}$ Dissenting opinion in the case concerning the Application of the International Convention on the Elimination of All Forms of Racial Discrimination (Georgia v Russian Federation) (Preliminary Objections) [2011] ICJ Rep 318, para. 201: International legal scholars in those days had more time to devote themselves to the fulfilment of the needs of the spirit; their energies were not yet diverted to, or consumed by, the distractions of the ages of television and internet. Modernity and post-modernity, with their characteristic pragmatism, seem to have obscured the goal of fulfilment of those needs, and to have left most people today apparently looking far too busy all the time, doing nothing substantial, certainly not thinking. ${ }^{7}$ Robert P Barnidge, Jr., 'The Contribution of Judge Antônio Augusto Cançado Trindade to the Adjudication of International Human Rights at the International Court of Justice' in James A Green, Christopher PM Waters (eds), Adjudicating International Human Rights. Essays in Honour of Sandy Gandhy (Martinus Nijhoff Publishers 2014) 49: For him, international lawyers have a sacred role to play in the world, and they must strive ever onward to expand the right of access to justice for all, in all possible situations, against all obstacles.
} 
comprising the foundation of Judge Cançado Trindade's conception. The efforts of the lawyer-internationalist should lead step-by-step to the birth of a new ius gentium, which should be a law "vital" for achieving the fundamental objective (ius necessarium). Judge Cançado Trindade places this in opposition to the concept of law resulting from the voluntarism of subjects of international law. It would seem that such a comprehensive image can be captured at the level of conceptualization of a framework for the system of international law, as what is essentially being discussed is its ideal type, conforming to the primary assumption. This approach runs the risk of having legal reasoning become the source of the international legal order. Indeed, there remains an open question as to the extent of acceptance for such an understanding of international law by its subjects, particularly states. Particularly when Cançado Trindade declares that legal conscience of what is necessary is superior to the free will of particular state actors. ${ }^{8}$ It would seem that the demand to favour conscience over the intention of a state ${ }^{9}$ in a collision with the will of states is primarily a persuasive device. Entities can thus be convinced to re-evaluate their approach to some aspects of international law. Similarly, international judges may engage in the effort to frame the analysed issues to make them aligned with the primary assumptions of the "necessary law" concept, ensuring achievement of the basic objective, which is the superiority of the individual. However, in this case as well it should be kept in mind that the ultimate value of a decision by an international court will depend on the consensual attitudes of parties to the proceedings ${ }^{10}$. Judges may thus employ interpretation to suggest their conviction as to the fairness of the decision. This, however, must be accompanied by conviction on the part of subjects of international law. Without it, ius necessarium remains an imagined collection of ideal principles, an ideal international legal order, a particular appeal or proclamation. There is no other path for it to achieve systemic success. This judicial conviction can assume a posture of demonstrating that only in this manner, with acknowledgement of the primacy of the individual over the state, and of the primacy of humanism over state interest ${ }^{11}$, can we avoid key paradoxes on the way to a comprehensive understanding and application of international law. The key expression in this context is the concept of recta ratio (right reason, right mindfulness) ${ }^{12}$, which

\footnotetext{
${ }^{8}$ Separate opinion in the case Whaling in the Antarctic (Australia, New Zealand $v$ Japan) [2014] ICJ Rep 382, para. 90: Juridical conscience of what is necessary (jus necessarium) stands above the "free-will" of individual States (jus voluntarium).

${ }^{9}$ Diss. op., Application of the International Convention on the Elimination of All Forms of Racial Discrimination (Georgia v Russian Federation) (n 6) 322, para. 214: conscience stands above the will.

${ }^{10}$ Insofar as such postures will not necessarily determine violations of the legal interests of third parties, unconditionally binding norms or the provisions of the UN Charter intended to maintain international peace and security.

${ }^{11}$ Diss. op., Application of the International Convention on the Elimination of All Forms of Racial Discrimination (Georgia v. Russian Federation) (n 6) 321, para. 210: The raison d'humanité prevails over the old raison d'Etat.

12 Andrzej Maryniarczyk, Polskie Towarzystwo Tomasza z Akwinu, Powszechna Encyklopedia Filozoficzna: Recta ratio (Greek: 'orthos logos') - a definition of human comprehension which, in the course of theoretical, practical and creative cognition, directed by the true, the good and the beautiful in ascertained things, becomes legal understanding ('rectus'); sometimes defined as eternal law (Godly), natural law, or Godly ideas which, as true, become indications of the proper functioning of the mind.
} 
is the source of a range of imperatives that, taken together, facilitate decoding of the essence of the international legal order. Judges and scholars understanding the essence of things are the natural depositories of recta ratio. It would seem that a particular path for eliminating the juxtaposition of the will of states with the imperatives of right reason would be acknowledgement that the latter may also be exhibited by representatives of states themselves. In this concept, a judge, a scholar, or the attorney of a state possessed of right mindfulness would thus become a sort of primary source for international law. Of particular importance would be equating the will of a state with the simple antecedents of right mindfulness.

\section{The "founding fathers" of international law}

In developing his conception, Judge Cançado Trindade reaches deeply into the views of the "founding fathers" of international law. Through appropriate selection and configuration, a relatively consistent picture is attained which leads to the conclusion that the effort to understand the international legal order through referencing its whole essence to the individual is a lasting element of that particular legal order. This has accompanied it since the very beginnings of its modern formula, and by the same token it should continue to impact its shape today. This foundation contains the formula presented by F. de Vitoria, according to whom "droit des gens" regulates the international community, comprised of individuals organized socially into states. In addition, we may also identify reference to the views of A. Gentil, who has indicated that the law of nations is law which regulates relations among individuals of a general entity, the community of nations (societas gentium). Cançado Trindade also invokes F. Suarez and his position that a community equated with the concept of humanity requires its own law, a regulator that allows for emphasis of that community's oneness and universality of character. This is only a short distance to the position of Grotius. Cançado Trindade accents his argument that the interest of the state has its natural limits. The state as an organizational form is not a goal in and of itself. Its existence should serve to protect the social order in accordance with the imperatives of right mindfulness, and it should constitute a path for perfecting the community of nations which encompasses all of humanity. Here Trindade reinforces his conception's framework by invoking S. Puffendorf, who claims that the law-giver is obliged to follow the natural law that proceeds from human reason, and the views of $\mathrm{C}$. Wolff that individuals in a particular association with states should strive for materialization of a common $\operatorname{good}^{13}$.

\footnotetext{
$<$ http://ptta.pl/pef/pdf/r/rectaratio.pdf $>$ accessed 07.12.2015.

${ }^{13}$ Sep. op., Unilateral Declaration of Independence (n 5) 552, para. 74: The droit des gens regulates an international community constituted of human beings socially organized in States and co-extensive with humankind (F. de Vitoria); thus conceived, it is solely law which regulates the relations among members of the universal societas gentium (A. Gentili). This latter (totus orbis) prevails over the individual will of each State (F. de Vitoria). There is thus a necessary law of nations, and the droit des gens reveals the unity and universality of humankind (F. Suárez). The raison d'Etat has limits, and the State is not an end in itself, but a means to secure the social order pursuant to the right reason, so as to perfect the societas gentium which comprises the whole of humankind (H. Grotius). The legislator is subject to
} 


\section{The Article 38 of the ICJ Statute}

One problem with the normative dimension of the conception by Judge Cançado Trindade under discussion here results from the necessity of phrasing it within the legal framework of Article 38 of the ICJ Statute. If the Hague tribunal is a court that rules on the basis of international law, all topics undertaken in separate or dissenting opinions concerning the essence of international law and associated legal status of the individual should strive for normative conclusions, as the fundamental objective of a judge is to strive for resolution of a legal dispute on the basis of applicable binding norms. The individual elements of Article 38 of the ICJ Statute therefore establish absolute borders for this reasoning ${ }^{14}$. Naturally, subject to the reservation that under consideration are proceedings effectively initiated before the Hague tribunal. We are therefore dealing with application of the concept of an international agreement, customary law, and general principles of international law acknowledged by civilized nations, as well as supplemental elements taken from international law jurisprudence and adjudication. Only through references to formal sources of international law may we speak of the normative context for the conception of the individual as expressed by Judge Cançado Trindade. Rejecting this framework would, as a consequence, necessitate searching for a separate justification for assessment of the role played by the individual in international law, and by the same token a likely change in the way the essence of international law is perceived.

In accordance with the assumptions adopted, and references to the opinions of the "founding fathers" of international law, Judge Cançado Trindade holds that the proto-source of all law is "the imperative of universal justice", which precedes both the idea of international law and the idea, secondary to it, of the state dimension of this legal order. ${ }^{15}$

It would seem that avoidance of a collision between natural law and the primarily positivist tendency in international law is possible in the views of Cançado Trindade through acknowledging that, in present international law, we are dealing with the adoption of a particular legation of natural law in the form of the recta ratio formula, which constitutes an integral and timeless element of the international legal order ${ }^{16}$. It would then be necessary

the natural law of human reason (S. Pufendorf), and individuals, in their association in the State, ought to promote together the common good (C. Wolff).

${ }^{14} \mathrm{Cf}$. Cançado Trindade (n 2) 116: Moreover, the enumeration of ,, sources" of International Law listed in Article 38 of the ICJ Statute was never meant to be, nor could it be, exhaustive. [...] It may thus be inferred that the formal sources of International Law are not static categories, but are rather in constant and dynamic interaction, reflecting, in a non exhaustive manner, the ways and means of manifestation of International Law in time.

${ }^{15}$ Separate opinion in the case concerning Questions relating to the Obligation to Prosecute or Extradite (Belgium v Senegal) [2012] ICJ Rep 556, para. 177: There is nothing extraordinary in this, if we keep in mind that, in historical perspective, international law itself precedes the inter-State dimension, and even the States themselves. What stands above all is the imperative of universal justice. This is in line with jusnaturalist thinking. The contemporary understanding of the principle of universal jurisdiction discloses a new, wider horizon. This is in line with jusnaturalist thinking. The contemporary understanding of the principle of universal jurisdiction discloses a new, wider horizon.

${ }^{16}$ Separate opinion in the case Ahmadou Sadio Diallo II (Republic of Guinea v Democratic Republic of the Congo) [2010] ICJ Rep 763, para. 106: The precious legacy of natural law thinking, evoking the natural law of the right human reason (recta ratio), has never faded away, and this should be stressed time and time again. 
to acknowledge that there is a rule present in international law which is immanently fixed, and whose validity does not require confirmation being sought in natural-law justifications of the international legal order.

\section{The new universal jus gentium}

According to Cançado Trindade, international law boasts a framework helpful in adapting this timeless value of law, and then assists in drawing practical, normative conclusions from it. It would seem that we should first invoke various types of modifications in international law, including the ceaseless efforts to distinguish a particular constant that would comprise a systemic counterweight to the process of fragmentation of international law. In Cançado Trindade's conception, this constant is referred to as the new universal jus gentium of our time, characterized by a far more human dimension. ${ }^{17}$ It is directly associated with the process of emancipation of the individual from the power of the state. Cançado Trindade treats this process as a result of the consolidation of international human rights law $^{18}$. In assessing this particular aspect of the conception under discussion, it should be said that, on the one hand, it constitutes a fixed element of the international legal order; on the other, it is an element whose importance is enhanced by transformations and evolution in international law. In this manner, the situational context becomes a factor enhancing the effectiveness of that consolidation. Going further, attention should also be drawn to the previously mentioned enhancement of the process of international law humanization. Cançado Trindade stresses that the rights of the individual should formally be matched with a range of duties incumbent upon states, at a minimum in the form of protection, investigation and prosecution of violations, enforcement of responsibility ${ }^{19}$. The systemic picture of int3ernational law, as captured by Cançado Trindade, takes into account not only the process of humanization, which can impact the manner in which the state is conceived of as a subject of international law, but also several other factors. This category most certainly includes strong invocation of the concepts of "the inherent dignity of the human person", "human conscience", "the universal juridical conscience", which, according to Cançado Trindade, is "the ultimate material source of all law". Among the determinants is also the concept of "realization of justice". In this case as well Cançado Trindade acknowledges that the realization of justice is best served by an environment divorced from voluntarism directed at seeking the consent of the state ${ }^{20}$. This leads to the simple conclusion that within the within the scope of the conception under

\footnotetext{
${ }^{17}$ Cançado Trindade (n 2) 27 et seq.

18 Sep. op., Questions relating to the Obligation to Prosecute or Extradite (Belgium v. Senegal) (n 15) 558, para. 184: [T] he emancipation of the individual from his own State is, in my understanding, the greatest legacy of the consolidation of the international law of human rights.

19 Ibidem: Not only individual rights, but also the corresponding State duties (of protection, investigation, prosecution, sanction and reparation) emanate directly from international law.

${ }^{20}$ Diss. op., Application of the International Convention on the Elimination of All Forms of Racial Discrimination (Georgia v Russian Federation) (n 6) 321, para. 209: This goal - the realization of justice - can hardly be attained from a strict State-centred voluntarist perspective, and a recurring search for State consent.
} 
discussion, many key phenomena and solutions are justified on grounds other than consensual agreements between states. In consequence, it should come as no surprise that strong emphasis is placed on the right of the individual to "access to justice" 21 . This is a logical extension of the imperative to realize justice. The same can be said about the right of the individual to damages for gross violations of innate human rights ${ }^{22}$. In light of this, there is nothing unusual in the reference by Cançado Trindade to the statement of Dillard contained in the advisory opinion as to the legal status of Western Sahara, that it is for the people to decide what happens with a territory that they inhabit, rather than for the territory to decide what happens with the people who inhabit it ${ }^{23}$.

Realizing justice is partially a form of reparations paid to the victim of a crime (here: an individual). For it to be fully realized, access to justice should be multidimensional. Cançado Trindade therefore distinguishes the following: the formal right to initiate proceedings, effective remedies, appropriate procedural guarantees, verdict and its enforcement. These are tools which allow for a full "enforcement" of the rights an individual is afforded within the confined of the international legal order ${ }^{24}$.

\section{The individual as a subject of international law}

Interesting from the perspective of the conception's clarity is its direct addressing of the issue of the individual's subjectivity. Cançado Trindade, in addressing the entirety of his considerations, states without hesitation that "individuals are indeed subjects of international law (not merely 'actors')",25, with a scope of rights and duties that emanate directly from international law. Cançado Trindade stresses that all attempts to depart from this assumption by international law doctrine would lead to catastrophic results. The subjectivity of the individual is confirmed in a range of international legal norms,

\footnotetext{
${ }^{21}$ See Sep. op., Unilateral Declaration of Independence (n 5) 602, para. 196. Cf. also Antônio Augusto Cançado Trindade, The Access of Individuals to International Justice, OUP 2011.

22 Separate opinion in the case of Ahmadou Sadio Diallo III (Republic of Guinea $v$ Democratic Republic of the Congo) [2012] ICJ Rep 355, para. 21: Successive grave violations of the rights of the human person (some on a massive scale) awakened human conscience to the need to restore to the human being the central position from where he had been unduly displaced by the exclusive inter-State thinking which prevailed in the nineteenth century. [...] The individual came again to be perceived as subject of the right to reparation for damages suffered.

${ }^{23}$ Sep. op., Unilateral Declaration of Independence (n 5) 549, para. 65: [It] is for the people to determine the destiny of the territory and not the territory the destiny of the people. [Separate opinion of Judge Dillard, Western Sahara (Advisory Opinion) [1975] Rep122].

${ }^{24}$ Dissenting opinion in the case concerning the Jurisdictional Immunities of the State (Germany v Italy: Greece intervening) [2012] ICJ Rep 289, para. 310: The right of access to justice lato sensu comprises not only the formal access to justice (the right to institute legal proceedings), by means of an effective remedy, but also the guarantees of the due process of law (with equality of arms, conforming the proces équitable), up to the judgment (as the prestation juridictionnelle), with its faithful execution, with the provision of the reparation due. The realization of justice is in itself a form of reparation, granting satisfaction to the victim. In this way those victimized by oppression have their right to the law (droit au Droit) duly vindicated.

${ }^{25}$ See Cançado Trindade (n 2) 240: This is not a juridical term, it is rather a term of art, to which no specific juridical contents and consequences are necessarily attached. To call individuals ,, actors” in International Law is nothing but a platitude. They are true subjects of International Law, bearers of rights and duties which emanate directly therefrom.
} 
comprising international human rights law, international humanitarian law, international refugee law and international criminal law. ${ }^{26}$ In light of this, the declaration that, in resolving the disputes brought before it, the International Court of Justice should not focus first on attempting to identify the consent of the states, but rather on striving to realize justice ${ }^{27}$, which in particular cases can prefer the subjectivity of the individual at the cost of states' subjectivity as a result of the greater weight of the values accompanying the individual. What follows is that the realization of justice is directly associated with the need to realize a set of values that demand protection of the individual at the cost of protection of the state ${ }^{28}$. Of course, Cançado Trindade does not reject consent of states as an important criteria helping to bring order to the entirety of international law. However, he applies the concept of presumption to the consent of states. This presumption implies that consent of states can, in some circumstances, be identified with the realization of justice; however, not in every case, as it must at times give way to the requirement of protection for the individual. The imperative for protection of the individual through giving it a particular sort of primacy over the consent of states is a higher-order value; by the same token, in the event of a collision it comprises a fuller realization of justice. Cançado Trindade expressed this presumption in a concise formula from which it results that the consent of states is only a means to an end, and not an objective in and of itself. It does not determine the results of efforts to interpret treaty obligations. In this context, taking the consent of states into consideration is merely a procedural requirement ${ }^{29}$. From the perspective of the primary notion accompanying the conception developed by Judge Cançado Trindade, this manner of capturing the issue is a natural consequence. There is no way to eliminate consent of entities as one of the key elements of reasoning designed to lead to legal conclusions that settle a dispute. However, if consent is merely an instrument, it should only be used as long as it serves the realization of justice, which itself is firstly protection of the individual, not of the state. The state, its will, and the consequences that flow from it should be protected to the extent they serve the protection of the individual, as this is the fundamental objective of the realization of justice.

In support of his reasoning, Cançado Trindade invokes the argument of Grotius that consent can never be treated as the ultimate source of legal obligations. This source can be identified in the formula pacta sunt servanda, treated as a general principle of law ${ }^{30}$.

\footnotetext{
${ }^{26}$ Diss. op., Jurisdictional Immunities of the State (Germany v Italy : Greece intervening) (n 24) 245, para. 180.

${ }^{27}$ Diss. op., Application of the International Convention on the Elimination of All Forms of Racial Discrimination (Georgia v Russian Federation) (n 6) 317, para. 198.

28 ibid 318, para. 202: The outcome of the present case before the ICJ, concerning the Application of the International Convention on the Elimination of All Forms of Racial Discrimination, is the ineluctable consequence of inaptly and wrongfully giving pride of place to State consent, even above the fundamental values at stake, underlying the CERd Convention, which call for the realization of justice.

${ }^{29}$ ibid 21-322, para. 211: State consent is but a rule to be observed in the exercise of compulsory jurisdiction for the realization of justice. It is a means, not an end, it is a procedural requirement, not an element of treaty interpretation; it surely does not belong to the domain of the 'prima principia'.

${ }^{30}$ ibid 317, para. 199: Hugo Grotius, for example, acknowledged that mere consent could
} 


\section{7. "Living instrument"}

The fundamental assumption of Judge Cançado Trindade leads to several important solutions in such areas as grasping the essence and the proper interpretation of a treaty. Its final effect is not, perhaps, original, but it does constitute one of the justifications for the application of objective-based interpretation. The justice applies the phrase "living instrument" in reference to treaties. He emphasizes that the constant, hermeneutic search for symptoms of consent of states-parties to a treaty renders it a dead letter. Particularly in reference to treaties concerning human rights protection, the basic approach should place a premium on the need to capture the spirit of such regulation ${ }^{31}$. Here it is worth underlining the obviousness of the fact that treaties addressing international protection of human rights constitute a prime example of this type of regulation. However, Judge Cançado Trindade ultimately extends his opinion to all documents which would essentially provide responses to the needs of the international community, and to the new challenges facing $\mathrm{it}^{32}$. In somewhat generalizing the thinking of Cançado Trindade, it should be noted here that the most deserving of the label "living document" and accompanying functional and objective-based interpretative imperatives are those international contracts whose substance renders them clear examples of the realization of justice, in the sense of their achieving the fullest possible degree of protection for the rights and freedoms of the individual.

\section{General principles of international law (prima principia)}

A characteristic feature of the entire conception is the strong accent placed on the sphere of values. In this approach, international law constitutes a type of guarantee for the realization of those values. They serve to protect the international community as a whole, rather than individual states ${ }^{33}$. These values are expressed in the general principles of international law, which weld together the entire international law system and ensure it achieves an essential level of cohesion. They are interwoven with the fundamental assumptions of the international legal order, thus imbuing it with the characteristic of universality, which, in turn, constitutes a source of benefits for humanity in genera $^{34}$. Judge Cançado Trindade perceives the source of these rules in

never be the ultimate source of legal obligations; a contract or a treaty (at domestic or international law levels) had binding effects on the parties by virtue of the underlying general rule of law of pacta sunt servanda.

31 ibid para. 198: The hermeneutics and proper application of that treaty cannot be continuously subjected to a recurring search for State consent. This would unduly render the letter of the treaty dead, and human rights treaties are meant to be living instruments, let alone their spirit.

${ }^{32}$ Sep. op., Whaling in the Antarctic (n 8) 358, para. 28 '[L]iving instrument' capable of keeping on responding to needs of the international community and new challenges that it faces nowadays in the present domain.

${ }^{33}$ Sep. op., Questions relating to the Obligation to Prosecute or Extradite (Belgium $v$ Senegal) (n 15) 556, para. 177: Furthermore, it transcends the inter-State dimension, as it purports to safeguard not the interests of individual States, but rather the fundamental values shared by the international community as a whole.

${ }^{34}$ Separate opinion in the Pulp Mills case (Argentina v Uruguay) [2010] ICJ Rep 214, para. 217: It is not surprising to find that voluntarist-positivists, who have always attempted to minimize the role of general principles of law, have always met the opposition of those who sustain the relevance of those principles, as ensuing from the idea of an objective justice, and guiding the interpretation and application of legal norms and rules. This is the position that I sustain. It is the principles of the inter-national legal system that can best ensure the 
"human conscience", a general legal awareness, which evolve into the final, substantive source of all law, including the international legal order ${ }^{35}$. From this perspective it is difficult to determine unequivocally whether the source of general principles as understood by Cançado Trindade is located within the system, or whether they are drawn from outside the sphere of the international legal order ${ }^{36}$. It would result from the conception under discussion that they constitute a shared and immanent characteristic of all legal orders. Without them, as Cançado Trindade stresses, there would be no legal order ${ }^{37}$. Constituting a counterweight to legal positivism ${ }^{38}$, they impact the interpretation of specific norms and verify their applicability ${ }^{39}$. In conjunction with the general principles of law, Cançado Trindade returns to ius necessarium, the essential substrate of every legal order that extends beyond a voluntarist justification for the binding force of legal norms ${ }^{40}$.

cohesion and integrity of the international legal system as a whole. Those principles are inter-twined with the very foundations of international law, pointing the way to the universality of this latter, to the benefit of humankind.

${ }^{35}$ ibid: Those principles emanate from human conscience, the universal juridical conscience, the ultimate material "source" of all law." Also ibid, para. 201: Every legal system has fundamental principles, which inspire, inform and conform to their norms. It is the principles (derived etymologically from the Latin principium) that, evoking the first causes, sources or origins of the norms and rules, confer cohesion, coherence and legitimacy upon the legal norms and the legal system as a whole. It is the general principles of law (prima principia) which confer to the legal order (both national and international) its ineluctable axiological dimension; it is they that reveal the values which inspire the whole legal order and which, ultimately, provide its foundations themselves. This is how I conceive the presence and the position of general principles in any legal order, and their role in the conceptual universe of law. Consistently in: Diss. op., Application of the International Convention on the Elimination of All Forms of Racial Discrimination (Georgia v Russian Federation) (n 15) 322, para. 213: These are some of the true prima principia, which confer to the international legal order its ineluctable axiological dimension. These are some of the true prima principia, which reveal the values which inspire the corpus juris of the international legal order, and which, ultimately, provide its foundations themselves. Prima principia conforms the substratum of the international legal order, conveying the idea of an objective justice (proper of natural law).

${ }^{36}$ Cf. Cançado Trindade (n 2) 86: The international legal order owes its effectiveness, its universality and its very existence to those principles.

${ }^{37}$ Separate opinion in the case of Interpretation of Judgment in the case of the Temple of Preah Vihear (Cambodia v Thailand) [2013] ICJ Rep 345, para. 66: Without them, there is ultimately no legal system at all.

${ }^{38}$ Separate opinion in the case Obligation to Negotiate Access to the Pacific Ocean (Bolivia $v$ Chile) (Preliminary Objection) 13, para. 40 with separate opinions (para. 20, paras 25-27) to ICJ orders in Certain Activities Carried out by Nicaragua in the Border Area (Costa Rica $v$ Nicaragua) and Construction of a Road in Costa Rica along the San Juan River (Nicaragua $v$ Costa Rica): Despite the characteristic attitude of legal positivism to attempt, in vain, to minimize their role, the truth remains that, without principles, there is no legal system at all, at either national or international level. $<$ http://www.icj-cij.org/docket/files/153/18750.pdf> accessed 07.01.2015.

${ }^{39}$ Sep. op., Interpretation of Judgment in the case of the Temple of Preah Vihear (Cambodia $v$ Thailand) (n 37) 337, para. 42: It is, ultimately, those principles that inform and conform the applicable norms.

${ }^{40}$ Sep. op., Obligation to Negotiate Access to the Pacific Ocean (Bolivia v Chile) (Preliminary Objection) (n 38) 13, para. 40 with separate opinions (para. 20, paras 25-27) to ICJ orders in Certain Activities Carried out by Nicaragua in the Border Area (Costa Rica v Nicaragua) and Construction of a Road in Costa Rica along the San Juan River (Nicaragua v Costa 
According to Cançado Trindade, exploration of general principals facilitates identification of the values which support the perception of equity and of justice, demonstrating their full worth only in conjunction with the need for protection of the individual ${ }^{41}$. This is a state of "objective justice", which flows from general, fundamental principles (prima principia). It should be emphasized that in this presentation the will of states is therefore incapable of overcoming objective justice; it must submit itself to that justice, acknowledging the supremacy of higher, humanist values which constitute an integral element of the international legal order, co-creating the source of general principles. Thus, justification for the binding force of general legal principles within the confines of the international legal order would be their association with the sphere of values which are appropriate for and characteristic of every legal order, not a sort of generalization and common denominator for all particular norms existing in international law.

Judge Cançado Trindade formulates a catalogue of general principles serving as a tool for the realization of objective justice, which attains its fullest dimension at the moment of protection of human conscience. He includes in them the principle of pacta sunt servanda, the principle of equality and prohibition of discrimination, the principle of procedural equality (equality of arms), the principle of humanism (humanity), itself constituting a generalization of international human rights and international humanitarian law, the principle of dignity of the human person, and a range of general principles of international law listed in Article 2 of the Charter of the United Nations ${ }^{42}$. Cançado Trindade explicitly excludes the principle of state consent from the scope of general principles of law (prima principia) ${ }^{43}$, which is a consequence of the assumption adopted earlier that consent is encompassed only by the presumption of expression of fundamental values that bring order to international law and allow for the realization of justice. It would seem that in this manner Cançado Trindade is attempting to remain formally within the confines of positive law, particularly when invoking the necessity of judicial resolution of international disputes.

\footnotetext{
Rica): General principles of law inform and conform the norms and rules of legal systems. In my understanding, sedimented along the years, general principles of law form the substratum of the national and international legal orders, they are indispensable (forming the 'jus necessarium', going well beyond the mere jus voluntarium), and they give expression to the idea of an objective justice (proper of jusnaturalist thinking), of universal scope.

${ }^{41}$ Sep. op., Interpretation of Judgment in the case of the Temple of Preah Vihear (Cambodia $v$ Thailand) (n 37) 337, para. 42: Het necessary attention to those principles brings us closer to the domain of higher human values, shared by the international community as a whole.

${ }^{42}$ Diss. op., Application of the International Convention on the Elimination of All Forms of Racial Discrimination (Georgia v Russian Federation) (n 6) 322, para. 212: Fundamental principles are those of pacta sunt servanda, of equality and non-discrimination (at substantive law level), of equality of arms (égalité des armes - at procedural law level). Fundamental principle is, furthermore, that of humanity (permeating the whole corpus juris of international human rights law, international humanitarian law, and international refugee law). Fundamental principle is, moreover, that of the dignity of the human person (laying a foundation of international human rights law). Fundamental principles of international law are, in addition, those laid down in Article 2 in the Charter of the United Nations.

${ }^{43} \mathrm{ibid}$, para. 213: In turn, State consent does not belong to the realm of the prima principia ; recourse to it is a concession of the jus gentium to States, is a rule to be observed (no one would deny it) so as to render judicial settlement of international disputes viable.
} 


\section{Ius cogens}

A characteristic element in the conception developed by Judge Cançado Trindade is linking the legal status of the individual with the necessity of realizing justice through the medium of general principles of law, of which a portion is characterized as ius cogens, unconditionally binding law. The primary objective of international law is to realize justice in a manner that guarantees the greatest possible extent of protection to the individual. Its tools are the general principles of law, which express values fundamental from the perspective of the elementary purpose of the international legal $\operatorname{order}^{44}$. An aspect which strengthens the capacity to achieve the assumed objective is imperativeness, especially of the fundamental principle determining every legal order. According to Cançado Trindade, the characteristic of iuris cogentis should be linked with the imperative of the realization of justice. ${ }^{45}$ It remains an open question whether this attribute should be applied to all consequences that proceed from this meta-principle. ${ }^{46}$ From the opinions expressed, we may observe the conclusion that ius cogens should doubtlessly be comprised of those general principles which express the highest values shared by the international community as a whole. From this perspective, ius cogens is, according to Cançado Trindade, an enhancement of the ethical dimension of international law interpreted as new jus gentium, that is, an international legal order designed to serve humanity ${ }^{47}$. Furthermore, the classification of a given principle (e.g. the prohibition on torture) to the category of unconditionally binding law is associated by Judge Cançado Trindade with acknowledgement of "obligations necessarily of

\footnotetext{
${ }^{44}$ Cf. Cançado Trindade (n 2) 310: Jus cogens appears indeed as a pillar of the new jus gentium, the International Law for Humankind. Jus cogens identified with general principles of law of material order, serves the superior interests of the international community as a whole; such interests, in turn, find expresion in the peremptory norms of International Law (jus cogens), emanating from the universal juridical conscience in each historical moment, and paving the way for the construction of a new jus gentium, the International Law for humankind. Jus cogens exists indeed for the benefit of human beings, and ultimately of humankind [footnotes omitted].

${ }^{45}$ Sep. op., Ahmadou Sadio Diallo III (Republic of Guinea v Democratic Republic of the Congo) (n 22) 382-383, para. 95: The realization of justice is of key importance to the victims, and belongs, in my understanding, to the domain of jus cogens. Without it, the right of access to justice 'lato sensu', there is no legal system at all.

${ }^{46}$ Cf. ibid 378, para. 81: The 'reparatio' for damages comprises distinct forms of compensation to the victims for the harm they suffered, at the same time that it re-establishes the legal order broken by wrongful acts (or omissions) - a legal order erected on the basis of the full respect for the rights inherent to the human person. The observance of human rights is the 'substratum' of the legal order itself. The legal order, thus re-established, requires the guarantee of non-repetition of the harmful acts. The 'realization of justice' thereby achieved (an imperative of 'jus cogens') is in itself a form of reparation (satisfaction) to the victims.

${ }^{4}$ Sep. op., Questions relating to the Obligation to Prosecute or Extradite (Belgium $v$ Senegal) (n 15) 557-558, para. 182: Identified with general principles of law enshrining common and superior values shared by the international community as a whole, jus cogens ascribes an ethical content to the new jus gentium, the international law for humankind. In prohibiting torture in any circumstances whatsoever, jus cogens exists indeed to the benefit of human beings, and ultimately of humankind.
} 
result", and not only "obligations of means and conduct"48. It is obvious that the adoption of this perspective strengthens the effectiveness of the conception. To expand, it is also not directly dependent on the consent of states, as it proceeds from meta-norms and the necessity to realize justice. The rule of state consent can strengthen this effect, but in this case it does not meet all of the criteria for a sine qua non condition.

\section{State immunity}

The construction of ius cogens in conjunction with grave violations of human rights and international humanitarian law allows Judge Cançado Trindade to explore aspects associated with the responsibility of the state towards the individual, and as a consequence the need to limit state immunity, if that immunity were to constitute a barrier to the realization of a constant feature in every legal order; this feature is referred to in the analysed conception as "rectitude" 49 . The views of Cançado Trindade on the legal character of state immunity are unambiguous. It cannot in any case constitute an element of an understanding which would weaken the imperative for the full realization of justice, particularly if that imperative were to revolve around the traditional necessity expressed in the conception of Cançado Trindade to secure justice for the victims of lawlessness. In his separate opinion entered into the advisory opinion concerning Kosovo's declaration of independence, the ICJ Judge left no doubt as to the scope of impact of unconditionally binding law on the extent to which a state's defence of immunity is effective. According to Cançado Trindade, an unconditionally binding norm which has as its object protection of the individual against all forms of grave lawlessness towards it enjoys superiority over the privileges and prerogatives comprising the institution of state immunity, most of all the immunity of the state and the possibility to engage in "denial of justice",50. Two elements are worthy of note in the reasoning presented herein. First, the protection that proceeds from state immunity may not draw on the necessity of protecting the interests of the state when it commits an offence against its own people, or the people of another state ${ }^{51}$. Secondly, international crimes of a state are neither iure gestionis nor iure imperii acts. They constitute a separate category, delictae imperii, not encompassed by any form of

\footnotetext{
48 ibid 555-556, para. 175: [T] he obligations under a "core human rights Convention" of the United Nations such as the Convention against Torture are not simple obligations of means or conduct: they are, in my understanding, obligations necessarily of result, as we are here in the domain of peremptory norms of international law, of jus cogens, generating obligations erga omnes partes under the Convention against Torture.

${ }^{49}$ Diss. op., Jurisdictional Immunities of the State (Germany v. Italy : Greece intervening) (n 24) 290, para. 313: Grave breaches of human rights and of international humanitarian law amount to breaches of jus cogens, entailing State responsibility and the right to reparation to the victims. This is in line with the idea of rectitude (in conformity with the recta ratio of natural law).

${ }^{50}$ ibid 286, para. 299: [State immunity] is not to stand in the way of the realization of justice. The pursuit of justice is to be preserved as the ultimate goal; securing justice to victims encompasses, inter alia, enabling them to seek and obtain redress for the crimes they suffered. Jus cogens stands above the prerogative or privilege of State immunity, with all the consequences that ensue therefrom, thus avoiding denial of justice and impunity.

${ }^{51}$ ibid 288, para. 305: When a State pursues a criminal policy of murdering segments of its own population, and of the population of other States, it cannot, later on, place itself behind the shield of sovereign immunities, as these latter were never conceived for that purpose.
} 
immunity $^{52}$. The acceptance of this assumption leads in an obvious fashion to the next conclusion that in the event of a grave violation of human rights or international humanitarian law, the individual must be afforded access to justice at the international level, and this law must be enforceable against the applicant's home state without recourse to various measures preventing the realization of justice in its simplest forms ${ }^{53}$. In the formal sphere, Judge Cançado Trindade reinforces the effectiveness of his reasoning through invoking the concepts of customary international law and the fundamental general principle of law, which are serve as primary sources of influence strengthening the individual's position vis a vis the state ${ }^{54}$. To help us comprehend the absolute necessity of such an understanding of the relationship between the state and the individual, Cançado Trindade invokes the potential legal absurdity that may result from revoking the immunity of states in some areas, such as international diplomatic and consular law, while retaining full immunity in the face of charges of grave violations of human rights or international humanitarian $\operatorname{law}^{55}$. All of these aspects reviewed in concert allow Judge Cançado Trindade to declare unequivocally that, in international law, state immunity does not apply in respect of international crimes, nor grave violations of human rights and international humanitarian law $^{56}$.

\section{The main function of a state}

A particular explication of the conclusion concerning withdrawal of state immunity in conjunction with a state being accused of committing an international crime or grave violation of human rights is a detailing of the scope of dependencies between the principle of territorial integrity and the principle of national self-determination. As Cançado Trindade emphasizes, the invocation of territorial integrity cannot serve as a veil behind which a state can commit international crimes and shield itself from an injured party or group ${ }^{57}$. Of key importance in his opinion is therefore acceptance of a

\footnotetext{
52 ibid, para. 306: International crimes perpetrated by States are not acts jure gestionis, nor acts jure imperii; they are crimes, delicta imperii, for which there is no immunity.

53 ibid, para. 307: In case of grave violations of human rights and of international humanitarian law, the direct access of the individuals concerned to the international jurisdiction is thus fully justified, to vindicate those rights, even against their own State.

54 ibid 289, para. 311: The State's duty to provide reparation to individual victims of grave violations of human rights and of international humanitarian law is a duty under customary international law and pursuant to a fundamental general principle of law.

${ }^{55}$ ibid, para. 312: In effect, to admit the removal of State immunity in the realm of trade relations, or in respect of local personal tort (e.g., in traffic accidents), and at the same time to insist on shielding States with immunity, in cases of international crimes - marked by grave violations of human rights and of international humanitarian law - in pursuance of State (criminal) policies, amounts to a juridical absurdity.

${ }^{56}$ ibid 290, para. 316: My firm position is that there is no State immunity for international crimes, for grave violations of human rights and of international humanitarian law.

${ }^{57}$ Sep. op., Unilateral Declaration of Independence (n 5) 593, para. 176: No State can invoke territorial integrity in order to commit atrocities (such as the practices of torture, and ethnic cleansing, and massive forced displacement of the population), nor perpetrate them on the assumption of State sovereignty, nor commit atrocities and then rely on a claim of territorial integrity notwithstanding the sentiments and ineluctable resentments of the "people" or "population" victimized.
} 
formula which leads to the conclusion that destruction of humanity is not a function of the state. The state, as an institution, exists for the individual, and not the individual for the state ${ }^{58}$. The wisdom of this conclusion is rather uncontroversial. Its detailing, however, can serve as an instrument leading to what are, at times, controversial solutions. Cançado Trindade claims that the government of a state which systematically and gravely violates the human rights of its own citizens or other groups of people thereby loses the right to represent them. In consequence, it should be added, it also loses the right to exist, as the sense of its being boils down to securing the status of the individual $^{59}$. It should be states clearly that associated over-interpretations, mistaken estimations of the systematic and grave nature of violations, or invocations of institutions regarding humanitarian intervention can easily be abused and lead to charges of interference in the internal affairs of other states $^{60}$.

\section{CONCLUSION}

In the judicial reasoning of Cançado Trindade, within the confines of the international legal order the individual is afforded the dimension it deserves, once account is taken of a range of components. There are references to both natural law and positivist frameworks invoked. The significance of their combination with each other emerges as only in concert can they facilitate reasoning leading to legally correct resolutions in international disputes concerning the status of the individual. Thus it is inevitable that the conception under discussion fulfils the requirements applied to a legal norm, insofar as it is to serve as the frame of reference for issuing a verdict.

The following elements comprise the determinants of the conception of the individual, repeated in individual and separate opinions delivered at the ICJ by Judge:

a) in issuing a verdict, a judge must invoke the essence of the legal order,

b) the essence of every legal system, and an essential characteristic of it, is the imperative of the realization of justice,

c) the source of the imperative of the realization of justice is rectitude, ratio recta, which carries natural-law connotations,

d) law which serves the realization of justice is necessary law (ius necessarium),

e) all of the aforementioned elements are equally applicable to international law,

f) ius necessarium is superior to ius voluntarium to the extent it is of

\footnotetext{
${ }^{58}$ ibid: The basic lesson is clear: no State can use territory to destroy the population. Such atrocities amount to an absurd reversal of the ends of the State, which was created and exists for human beings, and not vice-versa.

59 ibid 595, para. 180: The Government of a State which incurs grave and systematic violations of human rights ceases to represent the people or population victimized.

${ }^{60}$ For example, the arguments raised by Russia in its conflict with Ukraine, that the Ukrainian state had lose its sovereign rights to the Crimea (incapacity to represent the people inhabiting that territory), inter alia with a view to the intensity and character of suggested human rights abuses.
} 
greater service in effecting the realization of justice; in this sense, ius necessarium is of greater importance than the will of particular states,

g) a presumption obliges that ius voluntarium is compliant with ius necessarium; this is, however, a presumption iuris tantum,

h) ius necessarium co-creates the law of the international community, which is composed of individuals organized socially within the framework of states co-existing with humanity per se,

i) the law of the international community is a new ius gentium,

j) the subjects of the new iuris gentium are thus individuals, as the sense of realizing justice amounts to affording justice to the individual; there is therefore a general directive in effect of pro persone humane,

k) the source of the directive of pro persone humanae is a range of general principles of (international) law of an evaluative character; it is sometimes reinforced with the institution of customary international law,

1) formal reinforcement of key values for ius necessarium is preformed through the construction of iuris cogentis (peremptory norms);

m) systemic interpretation of international law taking into account ius necessarium expressed through unconditionally binding law leads to the appropriate hierarchization of international law norms,

n) the hierarchization of international law norms as described above can lead to significant re-evaluations; one of the necessary conclusions is acceptance of weakening the institution of state immunity, if this is a path leading to the realization of justice for an individual harmed by the state;

o) the entirety of the conception constitutes a proposal for a new narrative, while retaining the fundamental elements of the legal framework presently in effect ${ }^{61}$.

\footnotetext{
${ }^{61}$ This concerns particular elements of the conception constituting the subject of separate opinions. In this case, they therefore express agreement as to the character of the decision, while maintaining a separate line of reasoning leading to the ultimate solution to the legal issue at hand. An individual opinion constitutes disagreement as to the applicability of a given norm or the manner it is ascertained.
} 